\title{
Assessment of Moral and Ethical Issues of Examination Malpractices in Christian Faith Based Institution
}

\author{
Oladele Olubukola Olabode* \\ Department of Religious Education, Faculty of Education, The Nigerian Baptist Theological Seminary, Ogbomosho, Nigeria
}

\section{${ }^{*}$ Corresponding Author}

Oladele Olubukola Olabode

\section{Article History}

Received: 28.09.2019

Accepted: 06.10.2019

Published: 30.11 .2019

\begin{abstract}
Examination malpractice is becoming a widespread experience that there is likely no examination anywhere at all levels and outside the formal school system that is not marred with one form of sharp practice of examination malpractice or the other. It has become a great concern to Christian leadership in the educational sectors, leading to brainstorming on different approaches to curb the menace in institutions especially Christian faith based institution, It should be noted that schools in primary, post primary and higher colleges especially private-oriented institutions, usually have religious connotation, by both ownership and leadership at the establishment. Institutions that are Christian faith based provide considerable amount of time for religious instructions at school hours based on the principles and teaching of the Lord and Savior Jesus Christ, being discussed partly during students' class time, mealtime, leisure hours, prep-time or sometimes organizes period of worship aimed at students' orientation about spirituality, moral behaviors, relationships, and attitudes towards learning. However, there are certain issues that are not expected to be mentioned among believers, which are actually not to be mentioned in a Christian faith based institution that are gradually cropping and growing in Christian institutions-examination malpractices. Therefore, this paper looked at the holistic concept of examination practices from its moral and ethical perspective and proposing a transformational approach to curbing the practices in the Christian institution of learning.
\end{abstract}

Keywords: Assessment, Moral and Ethical Issues, Examination Malpractice, Christian Faith Based Institution.

\section{INTRODUCTION}

Establishment of schools from primary, post primary and through higher colleges especially private institutions, usually have religious connotation, by both ownership and leadership. Institutions that are Christian faith based provide considerable amount of time for religious instructions at school hours based on the principles and teaching of the Lord and Savior Jesus Christ, being discussed partly during students' class time, mealtime, leisure hours, prep-time or sometimes organizes period of worship aimed at students' orientation about spirituality, moral behaviors, relationships, and attitudes towards learning [1].

However, there are certain issues that are not expected to be mentioned among believers, which are actually not to be mentioned in a Christian faith based institution that are gradually cropping and growing in Christian institutions-examination malpractices. Jimoh [2] is of the opinion that examination malpractice is becoming a widespread experience that there is likely no examination anywhere at all levels and outside the formal school system that is not marred with one form of sharp practice of examination malpractice or the other. This has been a concern to Christian leadership in the educational sectors, brainstorming on different approaches to curb the menace in our institution especially Christian faith based institutions. Therefore, this paper seeks to look at the holistic concept of examination practices from its moral and ethical perspective and proposing a transformational approach to curbing the practices in the Christian institution of learning

\section{Concept of Examination Malpractices}

The alarming rate of increase in examination malpractice is not peculiar only to Nigeria or Africa alone, but has become a global issue, even among religious based institutions [2]. It has become so prevalent that in recent times, it is yearly practice both in internal and external examinations [3]. However, many scholars viewed examination malpractices from different perspectives; Argungy

Copyright @ 2019: This is an open-access article distributed under the terms of the Creative Commons Attribution license which permits unrestricted use, distribution, and reproduction in any medium for non commercial use (NonCommercial, or CC-BY-NC) provided the original author and source are credited. 
[4] defined examination malpractice as any irregularity that is intentional carried out by candidates or examination agents with the intention of gaining undue advantage over other students in examination. Jega [5] sees a form of misbehavior that leads to the alteration of or a tempering with the prescribed ways of conducting examination in any given system.

Ifeakor and Anekwe [3] present an improper or dishonest act in examination with an attempt to secure unmerited advantage, a massive and unprecedented abuse of rules and regulation pertaining to internal and public examination, starting from the construction of such examination, through the taking of the examination, the marking and grading, to the release of results and issuance of certificates. Onuka and Durowoju [6] viewed examination malpractice as any dishonest or unauthorized action or deed committed by a student on his own or in collaboration with others, acting unfairly with the intention to score more marks than what the natural ability and honest efforts would enable [7]. Therefore, examination malpractice is any act of omission or commission, which compromises the validity, reliability and integrity of any assessment or evaluation system [8].

\section{Forms of Examination Malpractice}

In every examination season, students tend to devise different clever ways of cheating in examinations; some of which are very challenging even for the most vigilant invigilators to detect. However, being a common global phenomenon, many scholars have identified different forms of examination malpractices as observed in Nigeria and other institutions of the world. However, the paper classifies these forms of examination into two namely: 'Self-induced and collaborative-induced cheating'.

Self-induced act connotes an individual student making a personal and deliberate plan to carry out examination malpractices, this involves bringing foreign materials into the examination hall such as textbooks, cribs, answered questions papers containing copious notes or used as disguise for current ones that have been smuggled out, photocopies of prepared answers. Writing notes on examination desks, walls, palms, clothes and electronic devices and students stretching out neck to spy and see what a fellow candidate has written down for a given question [9].

Collaborative-induced act involves two or more people conniving to deliberately involve in examination malpractices, this involves impersonation or misrepresentation, smuggling of answer scripts, procurement of answer booklets, examination leakages, mass cheating and dubbing in connivance with the school examination officers/invigilators or supervisors, other examination officials and parents sponsoring the process [10]. Others are collusion among candidates themselves and between them and officials in charge of Examinations, as well as deliberate delay of parcels submission by the supervisor, which is in agreement with some assigned supervisors. This arrangement gives the supervisors and touts enough time to complete the writings and rearrangement of the scripts [11].

\section{Causes of Examination Malpractice}

Scholars have acknowledged the certain reasons for examination practices which, Jimoh [2] presents as follows: Dishonesty in the society; little or no supervision of teachers by inspectors; sky-rocketing cost of enrolment in school fees; basing promotion of teachers to the success of candidates in public examinations; success at all cost syndrome; poor teaching in schools and inability to complete syllabus before examination. Others are lack of confidence on the part of teachers and students as well as absence of guidance and counseling services in schools.

Olajuwon [12] is of the opinion that overcrowding in schools and parents' contributions in paying for live papers and hire people to sit for examination on behalf of their wards are factors. In addition, the effect of the constant closure of schools is weakening academic excellence in schools, the disruption of academic calendars due to strikes, over-emphasis on examinations and certificate has given rise to examination malpractices, for academic excellence, skills and competency are sacrificed on the altar of certificate [13].

Moreover, poor living condition, poor remuneration of supervisors and other examination officials by the examination bodies could give rise to examination malpractice. Others factors that could be responsible for examination malpractice are; unconducive learning environment leading to ineffective teaching/learning activities, over value of certificates, decadence in the Nigerian society and parental support as suggested by other writers [14, 15].

\section{Effects of Examination Malpractice}

Scholars have expressed the enormousity and mind bugling effects of the consequences of examination malpractice on the nation, religious bodies, institutions, families and individuals. There have been irreversible loss of credibility of certificates; failure in job performance; imprisonment; rendering the goals of education invalid with its economic consequence on the nation [6, 16]. Examination malpractice is a social evil that has detrimental effect on ethical and moral values of the society, resulting in the quality of the nation's work force development indirectly proportion to the quality of its educational system [17].

Abdulkareem and Alabi [18] lament on examination malpractice as being responsible for production of poor labor force, and the value of certificates obtained through this practice becoming worthless. It has exhibited unhealthy attitudes and corrupt nature within the society leading to breeding and nurturing of fraudulent and dishonest behaviors as well as lifestyles of crime in different 
organizations and establishments; which Idahosa [19] believes are reflections of a lack of moral integrity in the educational system. Invariably, the continuous practice of examination malpractices might have been informed by the influence of the moral and ethical decadence that has developed over the time in the society [20].

The society nurtures cheats and mediocre turning them into celebrities, laying great emphasis on success goals without equivalent emphasis on institutional means of attaining these goals. The society celebrates success and wealth without a corresponding emphasis on legitimate means and avenues for such achievement [21]. Moreover, this same moral decadence informs students, parents, and teachers' involvement in examination malpractice. Students and parents are involved for good grades; while teachers and others for financial, material and other intangible gains derivable from involvement in this menace [22].

\section{Moral and Ethical Concern of Examination Malpractice}

Ethically, examination malpractice is a moral issue, for ethical issues deals with human actions [23], also is a normative principle which controls and influences individual behaviors and a nonnative science of human conduct basically evaluating human action [24]. It is obvious that a part of ethics is morality that deals with good or bad human conduct, which relates to what ought to be done; and examination malpractice falls into this aspect. Therefore, if there is any established constitution and consequences against this menace, then it implies moral decadence.

It is morality to advertise tutorial centers (Miracle or Special centers) to indulge in examination malpractice, these centers according to Igwe et al., [25] are patronized and sustained by students, supported and financed by parents, guardians and facilitated by teachers, school management including some Christian faith based institutions, law enforcement officials and communities these centers are situated. The centers place advertisements that beclouded the minds of those who patronize the expo centers, disguising and parading as tutorial centers.

Moreover, Igwe et al., [25] affirmed these Miracle centers organized lessons, home teaching hours and tutoring, while the practitioners maintain a modified remedial class rendering services to different categories of students in secondary school, undergraduates, graduates, postgraduates and adults. These centers help students to cheat and pass pubic examinations, by registering candidates and contracting an agent to seat for the examination while the registered candidates stay at home expecting good result later. A candidate may also register, sit for the examination and be aided by machineries in the examination halls.

Iloh [26] affirms a sense low of moral value on the parts of these centers' owners, by adopting criminality as a supposed legitimate source of livelihood. The concern is that people feel honorable to cheat and pass than to fail any public examinations. Parents who prefer securing admissions for children at all cost lack moral value, therefore, it takes teachers, school management, parents, students and invigilators with high integrity not to succumb to the pressures of allowing malpractices to take place in centers used for examinations.

Igwe et al., [25] expressed the fact that examination malpractices in public are now made very easy through globalization, as information and communications technology (ICT) has projected examination malpractices by making it possible for candidates to receive information from examination malpractice syndicate irrespective of the distance. It is also a function of moral decadence for students using handsets and other electronic appliances to facilitate the perpetration of examination malpractices, with the collaboration of those aiding and abating the students in the examination [26].

Ochuko [27], in analyzing the issue of examination malpractice, affirms it is morality on the part of the teachers, parents, examiners and law enforcement agents to discourage candidates from any form of examination malpractice, however, any form of involvement in this misconduct is a clear reflection of the moral corruption against the law of God and the land. He categorizes examination practice to have fallen short of Kant's categorical imperative of actions that could be recommended to others to embrace. After all, those involved in this misconduct are attracted by material gains, but not concerned about the harm caused to others; meanwhile they will try all available means to be free from this scandalous exercise, which connotes a deficiency in moral values.

Having examined both moral and ethical perspective on examination practices, the writer believes that perpetrators of this menace need a transformative process; therefore, this paper is proposing a transformational approach through the leadership of different institutions to curb this practice in the Christian institution of learning.

\section{Transformational Approach}

Transformational approach has been demonstrated effectively in many leading organizations [28], with great influence on subordinates' behavior and organizational outcomes [29]. However, "transformational approach aims at transforming people and organizations by changing individuals minds and hearts; enlarge vision, insight, and understanding; clarify purposes; make behavior congruent with beliefs, principles, and values; and bring about changes that are permanent, self-perpetuating, and momentum building" adapted from The Transformational Leadership Report 2007. 
However, transformational approach has no specific behavior, for behavior is a continuous process between followers and the leaders, invariably transformational approach effect changes to reach the organizational goals, by establishing relationship between leadership and followership. According to (Bass and Riggio 2005, adapted from the Transformational Leadership Book, 2007), transformational approach involves inspiring followers' commitment to a shared vision and goals for an organization or unit, challenging innovative problems solving attitudes, and developing followers' leadership capacity through coaching, mentoring, and provision of both challenge and support. This is an important factor for a transformational leader in a Christian faith based institution, possessing the characteristics or dimensions of transformational leadership as he interacts with those involve in examination activities for motivation and inspiration.

\section{Transformational Approach to Curbing Examination Malpractices}

Avolio and Bass' [30], identifies five components of idealized influence of transformational leadership, that builds confidence and sense of appreciation in the followers to accept radical changes in organization, which are idealized behavior, inspirational motivation, intellectual stimulation, individualized consideration and idealized attributes. These components exhibited at different times leadership makes the followers to honor, appreciate, trust, admire the leader, with the desire to identify with and imitate them [43].

Transformational leader with idealized behavior possesses personal idea that speaks of the importance of values and beliefs, specifying the significance of having a strong sense of purpose, understanding moral and ethical consequences of decisions, emphasizing the importance of students trusting in personal ability [31]. The leader encourages staff members, students and parents on the importance of values and beliefs, the need for a strong sense of purpose, considering the moral and ethical consequence of decisions relating to examination malpractices and talking to students on the importance of trusting in personal ability, not to be involved in any form of examination malpractices.

Inspirational motivation is the third component a transformational leader possesses- an ability to inspirationally motivate staff members; parents and students toward excellence performance and goals achievement. Inspirational motivation occurs when leaders inspire and motivate all that are involved in examination processes towards excellence performance without involving in examination malpractices. According to Bolden et al., [32], this leader talks hopefully about students' glorious future, talk passionately on how to avoid any form of malpractices in examination with the staff and students. Referring to Bass and Riggio [33] transformational leaders act to stimulate and enthuse staff, students and parents by providing meaning and challenge of examination malpractices to those concerned, to influence everyone to work hard, giving positive impact to the students indirectly.

Intellectual stimulation of the transformational leader explicates leaders' ability to stimulate the followers' endeavors for innovation and creativity [34], seeing new things in the old organizational problems, coming out with a new perspective [35]. The leader will rationally encourage the staff and students to become innovative, creative, and critical in thinking and problem solving on issues relating to examination. The leader encourages the students in problem-solving creativity tendency as he communicates and provides mentorship to the students [36].

Leaders with Individualized consideration provide support, encouragement, and instruction to followers [37]. The leaders listen carefully to staff, students and parents' needs and delegate certain responsibilities to help all grow through personal and collective challenges relating to examination [38]. Anderson and Ann Sherman [36] believed individualized consideration leader would create time to teach and instruct, treating students as individuals as well as groups, to develop their strength, assisting staff for strategies to facilitate students' learning and encourage parents to believe in their children ability.

Idealized attributes exhibited in a leaders help build respect, trust and faith in others who associate with them, acting to build others' respect, display a sense of power and competence, willingness to make personal sacrifices for others' benefit and reassure all that challenges will be overcome [31]. The leader becomes a role model to the staff and students as well as provides vision and a sense of mission especially to the students. This leader builds accountability tendency and consciousness in staff, students and parents to God and man in relations to their conduct during examination, which informs the need to do the right thing during examination [39]. The leader idealized attributes builds respect, trust and faith to their students to shun examination malpractices.

At no time, will leader with idealized influence utilizes position and abilities to achieve personal interests, but directed it to followers' potentials to achieve shared goals [40]. This leader presents his clear set of values related to examination malpractice, combined with his extraordinary capabilities, persistence, and determination to discourage examination malpractices from staff members, students and parents. The leader takes risk that is consistent to doing the right thing, demonstrating high standards of ethical and moral conduct, playing exemplary role models to staff, students, and parents, most importantly commanding the trust and respect from students to make right decisions against examination malpractices [33].

Moreover, if educational leaders in Christian faith based institutions apply transformation leadership approach, creating an environment that fosters an excellence culture to motivate student, encourage staff members and give hope to parents [41]. Leaders that will curb examination malpractices will build good relationships with staff, students, parents and examination agents concerned 
with examination processes to enhance students' well-being and work performance. These relationships also may connect the followers to the group more tightly through loyalty, gratefulness, and a sense of inclusion [42].

\section{CONCLUSION}

Every pre-meditated act either good or bad is both ethical and moral issue, and it is evidenced that examination malpractices are not accidental, but premeditated for obvious reasons of passing examination at all cost not minding the consequences to the integrity of individuals involved and educational system of the nation. However, this paper has explored an approach, which is transformational in nature, built on the integrity of the leadership to bring about a change through idealized influence on the staff, students, parents and other examination agents to curb examination malpractices. Transformational approach directs students toward effectiveness and productivity; motivating students toward extra effort, increasing students' inspiration to success, improving their performance beyond expectation and cultivating creativity and innovation among students.

\section{REFERENCE}

1. Aderogba, A. A., \& Olatoye, R. A. (2012). Do Religiously Committed Students Engage in Less Examination Malpractice Behaviours?. International Journal of Social Sciences \& Education, 3(1).

2. Jimoh, B. O. (2009). Examination Malpractice in Secondary School in Nigeria: What Sustains It?. European Journal of Educational Studies, 1(3): 10-108.

3. Ifeakor, A. C., \& Anekwe, J. U. (2010). Achieving Standard in Secondary Education through the Eradication of Examination Malpractices: The Nigerian Experience. African Research Review, 4(4): 357-377.

4. Argungy, M. A. (1997). Examination malpractices in tertiary institutions. Bichi Journal of Education, 1(1).

5. Jega, A. M. (2006). Examination malpractice: Concept, causes, consequences and remedies. Education for Today, 6(2), 59-72.

6. Onuka, A. O. U., \& Durowoju, E. O. (2013). Stakeholders' Role in Curbing Examination Malpractice in Nigeria. International Journal of Economy, Management and Social Science, 2(6): 342-348.

7. Okendu, J. N. (2012). Strategic Program Development and Examination Malpractices. Developing Country Studies, 2(5): $22-29$.

8. Shonekan, M. (1996). Promoting the Ethics and Integrity of WAEC Examinations in Onyechere I (eds) Promoting Examination Ethics, the Challenge of a Collective Responsibility, Exam Ethics Project Publication, Lagos.

9. Akaranga, S. I., \& Ongong, J. J. (2013). The Phenomenon of Examination Malpractice: An Example of Nairobi and Kenyatta Universities. Journal of Education and Practice, 4(18).

10. Arifayan T. (2004). Examination Malpractice: Who Is To Blame I, II, III" Daily Times, Thursday June 3, 4th and $7^{\text {th }}$.

11. Gbagolo, H. (2011).Examination Malpractices in Nigeria: A Review of Literature. Continental Journal Education Research, 4(3): 34-43.

12. Olujuwon, T. (2006). Transforming the Nigerian Educational System. Department of Educational Foundation, Lagos: Adeniran Ogunsanya College of Education.

13. Ayua, F. A. (2006) Confronting Legal Issues in Examination Malpractice: The Law, Prosecution, and JudicialProcesses. Speech Delivered at a Two-Day Summit on Examination Malpractice in Nigeria Organized by the House of Representatives committee on Education. Held at the Shehu Musa Yar'Adua centre, Abuja, August 15-16.

14. Nwadiani, M. (2005). Curbing Examination Malpractice in the Nigerian Educational System. A Lead Paper presented at the First Annual Conference of the Faculty of Education, Abrose Alii University Ekpoma, November 10-12.

15. Badmus, G. A. (2006) Accountability in Teaching Learning Environment and Examination Malpractices. A Paper presented at a Two-Day Summit on Examination Malpractice in Nigeria organized by the House of Representative Committee on Education held at the Shehu Musa Yar'Adua centre, Abuja, August 15-16, 2006.

16. Chukwuka, C. (2013). Examination malpractice- Role of teachers in Anambra state. Retrieved November 11, 2018 from www.doublegist.com/examination...state/

17. Ogunkola, B. J. (2011). Curtailing Malpractice in Public Examinations: A higher continuous Assessment Score option. http://naere.org.ng/joumal/complete.pdf.

18. Abdulkareem, A. Y., \& Alabi, A. T. (2004). Curbing examination malpractice in the university system: A managerial perspective. www.naere.org.ng/journal/concept curbing_examination_malpractice... Retrieved November 10, 2018.

19. Idahosa, M. C. (2004). Perceived Causes of Malpractice in Public Examination by Fresh students of St. Augustine"s college of education, Akoka, Lagos. Retrieved from www.naere.org.ng/journal/perceived_causes_malpractice_exam

20. Martins, C. (2013). Eradication of examination malpractice. Retrieved November 10, 2018 from martinslirary.blogspot.co.ke/2013/03/eradication-of-examination-malpractice.html?m=1

21. Adewale, G. (2011). Examination malpractice: A stigma on school effectiveness in Nigeria Retrieved from www.naere.org.ng/journal/sxaminationmalpractice-stigma-school-pdf November 20, 2018

22. Ojerinde, D. (2001). Private Schools, Centres of Exam Fraud NECO Boss. The Nigerian Observer, 3.

23. Omoregbe, J. (1993). Ethics: A Systematic and Historical Study. Lagos: Joja Educational Research and Publishers.

24. Hornby, A. S. (2002). Oxford Advanced Learners Dictionary of Current English. London: Oxford University Press.

25. Igwe, O. I., Ogadi, C., \& Nwokobia, C. U. (2018). Special (Miracle) Centres: Blessing or Curse to Secondary School External Examinations in Nigeria? International Journal of Research Development. Retrieved on 08/12/2018

26. Iloh, C. (2010) Practicum in classroom management and organization. Revised edition. Agbor - Nigeria: Printing Associates. 
27. Ochuko, O. (2011). Ethical Dimension in Examination Malpractice, in Nigeria Journal of Education, Health and Technology Research (NJEHETR), 1(1).

28. Felf, J., \& Schyns, B. (2004). Is similarity in leadership related to organizational outcomes? The case of transformational leadership. Journal of Leadership and Organizational Studies, 10(4), 92-102.

29. Tickle, E. L., Brownlee, J., \& Nailon, D. (2005). Personal epistemological beliefs and transformational leadership behaviours. Journal of Management Development, 24(8), 706-719.

30. Avolio, B. J., \& Bass, B. M. (1995). Individual consideration viewed at multiple levels of Analysis: A multi-level framework for examining the diffusion of transformational leadership. The Leadership Quarterly, 6(2), 99-218.

31. Avolio, B. J., \& Bass, B. M. (2004). Multifactor leadership questionnaire manual and sampler set (3rd ed.). Palo Alto, CA: Mind Garden.

32. Bolden, R., Gosling, J., Marturano, A., \& Dennison, P. (2003). A review of leadership theory and competency frameworks. Centre for leadership studies, University of Exeter.

33. Riggio, R. E., Chaleff, I., \& Lipman-Blumen, J. (Eds.). (2008). The art of followership: How great followers create great leaders and organizations (Vol. 146). John Wiley \& Sons.

34. Limsila, K., \& Ogunlana, S. O. (2008). Performance and leadership outcome correlates of leadership styles and subordinate commitment. Engineering, Construction and Architectural Management, 15(2), 164-184.

35. Moss, S. A., \& Ritossa, D. A. (2007). The impact of goal orientation on the association between leadership style and follower performance, creativity and work attitudes. Leadership \& Organization Development Journal, 3(4), 433-456.

36. Anderson, K., \& Sherman, A. (2008). Re-examining the Reciprocity of Principal and Teacher Leadership: Distribute Leadership and the Search Transformational Teacher Leadership University of New Brunswick and University of Calgary, Canada.

37. Yukl, G. (2006). Leadership in organizations (6th ed.). Upper Saddle River, NJ: Pearson Education, Inc.

38. York-Barr, J., \& Duke, K. (2004). What do we know about teacher leadership? Findings from two decades of leadership, Review of Educational Research, 74(3), 255-316.

39. Treslan, D. (2006). Transformational leadership in the classroom: Any evidence? Education Canada Spring, 46(2).

40. Lewis, S. (2013). How can I create a positive work environment during cutbacks? Strategic HR Review, 12(6).

41. Ibrahim. M. S. (2011). Multi-dimensional leadership orientation and lecturers' work commitment. A mediating effect in leadership effectiveness among Malaysian polytechnic's heads of department.

42. Hogg, M. A., Martin, R., Epitropaki, O., Mankad, A., Stevensson, A., \& Weeden, K. (2005). Effective leadership in salient group: Revisiting leader-member exchange theory from the perspective of the social identity theory of leadership. Personality and Social Psychology Bulletin, 13(7), 991-1004.

43. Halan, J. M. (2004). Protecting Trade Secrets: Steps Every Trade Secret Owner Should Know. EMP. REL. LJ, 30, 22. 